\title{
Hubungan antara Kecemasan dan Kadar Kortisol terhadap Kejadian Premenstrual Syndrom
}

\section{${ }^{1}$ Dia Rianti}

\begin{abstract}
ABSTRAK
Pendahuluan salah satu masalah kesehatan reproduksi yang sering dialami oleh wanita dan merupakan masalah utama dalam masyarakat adalah gangguan menstruasi. Gangguan ini sering merupakan sumber kecemasan bagi wanita. Gangguan yang sering terjadi antara lain siklus menstruasi yang tidak teratur, gangguan volume menstruasi baik perdarahan yang lama atau abnormal, gangguan nyeri atau dismenorrhea, atau sindroma pramenstruasi. Penelitian ini bertujuan menganalisis Tingkat kecemasan dan Kadar Kortisol pada wanita usia reproduksi sehat terhadap kejadian Premenstrual Syndrom pada mahasiswi DIV Kebidanan STIKes Mega Rezky Makassar
\end{abstract}

Metode penelitian ini bersifat analitik observasional dengan rancangan cross-sectional study. Pengambilan Sampel sebanyak 40 responden dengan teknik purposive sampling. Teknik pengumpulan data yang digunakan adalah kuesioner, wawancara dan observasi. Penelitian dilaksanakan pada 01 Juni sampai dengan 14 Juli 2017 di STIKes Mega Rezky Makassar untuk mendapatkan data PMS dan Cemasnya sedangkan untuk data kortisolnya di Laboratorium Universitas Hasanuddin Makassar

Hasil penelitian menunjukan bahwa Kecemasan dan kadar kortisol mempengaruhi terjadinya Pre menstrual Syndrom dengan nilai Sig Model $0.00<0.05$, dari kedua variabel tersebut kortisol merupakan penyebab langsung terjadinya Pre menstrual syndrom dengan nilai OR 2.530 yang berarti kortisol yang tidak normal memiliki kecenderungan 2.5 kali lipat mengalami Pre menstrual syndrom dibanding kortisol yang normal.

Kesimpulan kecemasan dan kadar kortisol mempengaruhi terjadinya premenstrual syndrome, dari kedua variabel tersebut kortisol merupakan penyebab langsung terjadinya premenstrual syndrome. Perlunya pendidikan kesehatan tentang pre menstrual syndrome pada mahasiswi melalui pendekatan teori ataupun praktek yang lebih komprhensif selain itu penelitian ini memiliki beberapa keterbatasn dalam pelaksanaannya, tidak ditemukannya hubungan yang positif antara kecemasan yang dialami subjek penelitian dengan premenstrual syndrome.
*AKBID Lapatau Bone

*diarianti@gmail.com
Kata kunci :

Kecemasan;

Kortisol;

Premenstrual Syndrom

\section{PENDAHULUAN}

Salah satu masalah kesehatan reproduksi yang sering dialami oleh wanita dan merupakan masalah utama dalam masyarakat adalah gangguan menstruasi. Gangguan ini sering merupakan sumber kecemasan bagi wanita. Gangguan yang sering terjadi antara lain 
siklus menstruasi yang tidak teratur, gangguan volume menstruasi baik perdarahan yang lama atau abnormal, gangguan nyeri atau dismenorrhea, atau sindroma pramenstruasi. (Sasaki, 2014).

Gangguan menstruasi yang sering kali muncul pada wanita adalah Sindroma Premenstruasi (PMS). Premenstrual syndrome merupakan gangguan siklus yang umum terjadi pada wanita muda dan pertengahan, ditandai dengan gejala fisik dan emosional yang konsisten, terjadi selama fase luteal pada siklus menstruasi dan lebih dari $90 \%$ wanita mengalami Sindroma Premenstruasi (Balaha et al., 2010). Delapan sampai dua puluh persen diantaranya bahkan mengalami gejala yang berat sehingga memerlukan pengobatan (Delara et al., 2012).

Berdasarkan laporan WHO (World Health Organization), prevalensi PMS cenderung lebih tinggi di beberapa negara Asia dibandingkan dengan negara-negara Barat (Mohamadirizi \& Kordi, 2013). Hasil penelitian American College Obstetricians and Gynecologists (ACOG) di Sri Lanka tahun 2012, melaporkan bahwa gejala PMS dialami sekitar 65,7 remaja putri. Hasil studi Mahin Delara di Iran tahun 2012, ditemukan sekitar 98,2\% perempuan yang berumur 18-27 tahun mengalami paling sedikit 1 gejala PMS derajat ringan atau sedang. Prevalensi PMS di Brazil menunjukkan angka 39\%, dan di Amerika 34\% wanita mengalami PMS. Prevalensi PMS di Asia Pasifik, di ketahui bahwa di Jepang PMS dialami oleh $34 \%$ populasi perempuan dewasa, Hongkong 17\%, Pakistan 13\%, Australia 44\% perempuan dewasa (Basir dkk., 2011).

Prevalensi PMS di beberapa daerah di Indonesia menunjukkan hasil yang berbeda. Di Jakarta Selatan menunjukkan 45\% siswi SMK mengalami PMS. Di Kudus didapatkan prevalensi PMS pada mahasiswi Akademi Kebidanan sebanyak 45,8\%. Di Padang menunjukkan 51,8\% siswi SMA mengalami PMS, sedangkan di Purworejo pada siswi sekolah menengah atas, prevalensi PMS sebanyak 24,6\%. Di Semarang tahun 2003 didapatkan prevalensi kejadian PMS sebanyak 24,9\% (Pratita \& Margawati, 2013).

Gejala yang timbul pada seseorang yang mengalami PMS dapat bermacam-macam, mulai dari gejala yang ringan hingga yang berat (Balaha et al., 2010). Gejala gangguan mood atau emosional dapat berupa perasaan tertekan/ depresi, cepat marah, emosi labil, cepat menangis, cemas, kebingungan, ingin menyendiri, konsentrasi menurun, insomnia, 
peningkatan keinginan untuk istirahat, dan perubahan pada hasrat seksual. Gejala perubahan atau gangguan fisik dapat berupa peningkatan keinginan untuk makan dan minum, payudara mengeras, berat badan meningkat, sakit kepala, bengkak pada ekstrimitas, pusing, nyeri, cepat merasa lelah, masalah pada kulit, gejala pada saluran pencernaan, serta nyeri pada abdomen (Delara, 2012 ; Kathleen, 2010).

Berbagai masalah emosional yang paling umum dialami wanita saat PMS adalah timbul suatu kecemasan ketika menghadapi PMS. Masalah PMS ini sering menjadi sumber kecemasan bagi wanita, terdapat sekitar 20\% kecemasan yang diakibatkan oleh sindrom pramenstruasi dari populasi dunia dan sebanyak $48 \%$ dialami oleh wanita usia subur (Yinghui et al., 2011). Prevalensi gangguan kecemasan akibat sindrom pramenstruasi di Indonesia diperkirakan berkisar antara 9\%-12\%. Presentase tingkat kecemasan karena sindrom pramenstruasi pada wanita yang melakukan konsultasi di LSM Rifka Annisa Women's Crisis Center (Rifka Annisa WCC) Yogyakarta tahun 2013 didapatkan pada wanita yang berusia di bawah 30 tahun yaitu 33,3\% dan wanita di atas 30 tahun yaitu 66,7\% (Lestari, 2015).

Penyebab pasti munculnya kecemasan dalam menghadapi premenstrual syndrome diantaranya adalah faktor hormonal pada tubuh wanita, yaitu ketidak seimbangan antara hormon estrogen dan progesteron. Kecemasan yang tidak diatasi segera akan dapat menimbulkan berbagai respon kecemasan, antara lain gelisah, keringat dingin, takut, dan berbagai gangguan kesehatan yang dapat mengganggu aktivitas sehari-hari (Wahyuni, 2012).

Mahasiwa merupakan Salah satu populasi yang cukup berisiko mengalami stress secara psikologis atau kecemasan, terutama yang baru memasuki tahun pertama (Balaha et al., 2010). Penelitian lainnya menyebutkan bahwa lebih dari 50\% mahasiswi mengalami sindrom pramenstruasi mulai dari gejala yang ringan sampai berat (Mahajan, 2010).

Stikes Mega Rezky memiliki populasi mahasiswa yang cukup banyak. Salah satunya Mahasiswa kebidanan. Studi pendahuluan yang dilakukan oleh peneliti didapatkan bahwa banyak mahasiswa yang ditemukan dengan premenstrual syndrom dengan gejala fisik seperti sakit kepala, cepat merasa lelah, gangguan pada saluran pencernaan, nyeri pada abdomen sedangkan Gejala Psikologis seperti cepat marah, kebingungan, konsentrasi menurun, payudara mengeras serta mudah cemas. 
Pramenstruasi yang mengakibatkan kecemasan dan peningkatan kadar kortisol bisa berdampak negatif pada diri mahasiswa jika tidak ditindaklanjuti. Untuk itu peneliti tertarik untuk melihat Tingkat kecemasan dan Kadar Kortisol terhadap kejadian Premenstrual Syndrom pada mahasiswa DIV Kebidanan STIKes Mega Rezky Makassar.

\section{METODE PENELITIAN}

Penelitian ini dilaksanakan di STIKes Mega Rezky Makassar. Jenis penelitian adalah Analitik Observasional dengan pendekatan Cross-Sectional untuk memperoleh informasi tentang analisis hubungan antara kecemasan dan kadar kortisol terhadap kejadian Premenstrual Syndrome pada mahasiswa DIV Kebidanan STIKes Mega Rezky Makassar

Populasi dalam penelitian ini adalah Mahasiswa DIV Kebidanan STIKes Mega Rezky dengan usia reproduksi sehat dengan indikasi Premenstrual Syndrome sebagai kasus dan wanita non Premenstrual Syndrome sebagai pembanding. Pengambilan sampel dalam penelitian ini menggunakan purposive sampling yaitu semua Mahasiswa DIV Kebidanan STIKes Mega Rezky yang dipilih berdasarkan penilaian peniliti (memenuhi persyaratan) dari populasi terjangkau dengan kriteria Inklusi sebagai berikut 1) Mahasiswi kebidanan DIV program reguler yang masih berstatus aktif, 2) Berusia 20 - 30 tahun, 3) Bersedia menjadi responden dengan mengisi kuisioner "Premenstrual dan Anxiety Screning Tools" dan bersedia di ambil Salivanya, 4) Siklus Haid Normal (28 Hari).

Pengolahan data dilakukan dengan tahapan: 1) Editing data yaitu memeriksa kembali kebenaran pengisisan data, kelengkapan data, kesinambungan data dan keseragaman data, 2) Koding data yaitu memberikan simbol-simbol dari setiap jawaban responden, 3) Cleaning data dilakukan pada semua lembar kerja untuk membersihkan kesalahan yang mungkin terjadi selama proses input data, 4) Tabulasi data yaitu data diolah dan disajikan dalam bentuk tabel.

Analisa data pada penelitian ini dengan mengunkan sistem komputerisasi yaitu Uji Statistik menggunkan aplikasi SPSS 22.0 yang dimasukkan kedalam master tabel kemudian ditabulasi sesuai variabel yang diteliti dengan menggunakan Uji Fisher's exact test dan uji regresi Logistic dengan tabel 2 x 2 untuk mencari perbedaan antara dua variabel dengan tingkat kemaknaan $\mathrm{p}<0,05$ artinya Ho di tolak berarti ada hubungan antara kecemasan dan kadar kortisol dengan kejadian Premesntrual Syndrome. 


\section{HASIL PENELITIAN}

Hasil penelitian ditemukan bahwa terdapat $36(90 \%)$ responden yang berumur 21-25 sedangkan kelompok umur 26-30 sebanyak 4 (10\%), rata-rata responden mengalami Menarche (haid pertama) pada umur 12-16 tahun yaitu sebanyak 37 (92.5\%) responden, $<12$ sebanyak $2(5.0 \%)$ responden dan $>16$ tahun sebanyak $1(2.5 \%)$ responden. Sedangkan responden yang memilik Indeks Massa Tubuh dari 18.5-29.9 kg/m² sebanyak 34 (85\%) dan $<18.5 \mathrm{~kg} / \mathrm{m}^{2}$ sebanyak 6 (2.5) responden. Untuk status pernikahan sebagai besar responden belum menikah $35(87.5 \%)$ dan sisanya $5(12.5 \%)$ yang sudah menikah. Hasil Penelitian menunjukkan bahwa dari 40 responden sebanyak 27 (67.5\%) PMS dan 13 (32.5\%) tidak PMS, selanjutnya 28 (70\%) responden mengalami kecemasan dan 12 (20\%) tidak cemas, dan untuk kadar kortisiol responden dengan kategori normal sebanyak 12 (70\%) sedangkan sisanya sebagian besar tidak normal $28(70 \%)$.

Uji Statistik menunjukkan bahwa dari 27 responden yang mengalami PMS sebanyak 25 responden (89.3\%) yang positif cemas sedangkan yang tidak cemas $2(16.7 \%)$ responden dan dari 13 responden yang Non PMS terdapat 3 orang yang mengalami cemas sedangkan sisanya $10(83.3 \%)$ negatif cemas. Berdasarkan perhitungan fisher's exact test, diperoleh nilai signifikansi atau $P$ Value $=0.000<\alpha 0.005$ dimana Ho ditolak dan Ha diterima yang berarti ada hubungan antara kecemasan dengan kejadian Premenstrual Syndrome pada mahasiwi DIV Kebidanan di STIKes Mega Resky Makassar sedangkan hubungan kadar kortisol dengan kejadian premenstrual syndrome ditemukan mempunyai hubungan setelah Ho ditolak dengan melakukan fisher's exact test dan ditemukan bahwa $P$ Value $=0.000<\alpha 0.005$ yang berarti Kadar kortisol mempunyai hubungan dengan kejadian Premenstrual Syndrome pada mahasiwi DIV Kebidanan di STIKes Mega Resky Makassar. Selain itu juga ditemukan data lainnya melalui Cross Tabulation yaitu dari 27 responden yang mengalami PMS tedapat 26 (92.\%) responden yang memiliki kortisol tidak normal sedangkan yang normal hanya 1 (8.3\%) dan dari 13 responden yang non PMS terdapat 2 (7.1\%) responden yang kadar kortisolnya tidak normal sedangkan yang kortsiolnya normal sebanyak 11 (91.7\%) responden.

Untuk mengetahui hubungan antara kecemasan dan kadar kortisol dengan kejadian premenstrual syndrome pada responden maka di lakukan uji regresi logistik dan ditemukan bahwa antara cemas dan kadar kortisol memiliki hubungan secara bersama-sama ataupun 
simultan terhadap kejadian premenstrual syndrom yang dibuktikan dengan nilai Sig. Model atau $P$ Value sebesar 0.000 sehingga Ho ditolak karena nilainya lebih kecil dari 0.05 maka dapat disimpulkan bahwa variabel bebas yang digunakan (kecemasan dan kadar kortisol) secara simultan atau bersama-sama mempunyai hubungan dengan kejadian premenstrual syndrome pada mahasiwi DIV Kebidanan di STIKes Mega Resky Makassar.

Dari dua variabel independen tersebut yakni kecemasan dan kortisol juga ditemukan bahwa yang mempunyai hubungan parsial yang signifikan terhadap premenstrual syndrome dari kedua variabel tersebut adalah kortisol dengan nilai Sig Wald $0.047<0.05$ sehingga menolak Ho yang berarti variabel kortisol memiliki hubungan parsial yang signifikan terhadap kejadian premenstrual syndrome sedangkan variabel cemas tidak memiliki hubungan parsial yang signifikan karena nilai sig wald $0.233>0.05$ sehingga Ho diterima yang berarti cemas tidak memiliki hubungan parsial yang signifikan

\section{PEMBAHASAN}

Penelitian ini menemukan bahwa antara kecemasan dan kortisol memiliki hubungan yang simultan atau bersama-sama terhadap kejadian Premenstrual Syndrome pada mahasiswi DIV kebidanan di STIKes Mega Resky Makassar. Hasil ini berdasarkan uji statistik Regresi Logistic biner yang diperoleh nilai Sig. Model atau $P$ Value sebesar 0.000. Karena nilai ini lebih kecil dari 5\% atau 0.05 maka kita menolak Ho ditolak dan Ha diterima sehingga dapat disimpulkan bahwa variabel bebas yang digunakan (kecemasan dan kadar kortisol), secara simultan atau bersama-sama mempunyai hubungan dengan Kejadian Premenstrual Syndrome.

Hal ini sejalan dalam penelitian yang dilakukan Hompes D, seorang ahli ginekologi Inggris pada tahun 2009, menjelaskan pengaruh kecemasan ataupun stres baik fisik, emosi dan lingkungan yang dialami oleh seseorang terhadap aksis hipotalamus-pituitari-adrenal atau pelepasan hormon kortisol. Peningkatan konsentrasi kortisol plasma secara generalnya proporsional dengan intensitas stimulasi stres: peningkatan level kortisol yang lebih besar, menandakan adanya respon terhadap kejadian stres berat dibanding kejadian stres yang sederhana (Sherwood, 2010). Kadar kortisol saliva $\geq 0,116 \mathrm{~g} / \mathrm{dl}$ dapat menjadi petanda bahwa sudah terjadi sindroma premenstruasi sedang-berat (Suparman \& Ivan, 2011). 
Stres ataupun kecemasan bisa mempengaruhi sekresi kortisol. Peningkatan dramatis sekresi kortisol, dimediasi oleh sistem saraf pusat melalui peningkatan aktivitas sistem corticotropin-releasing hormone (CRH)-Adrenocorticotopic hormone (ACTH)-kortisol, terjadi dalam respon terhadap situasi yang menyebabkan stress ataupu kecemasan. Sekresi kortisol berhubungan dengan cemasan dan Pre menstrual Syndrom. Peningkatan dramatis sekresi kortisol, dimediasi oleh sistem saraf pusat melalui peningkatan aktivitas sistem corticotropin-releasing hormone (CRH)-Adrenocorticotopic hormone (ACTH)-kortisol, terjadi dalam respon terhadap situasi yang menyebabkan cemas. Peningkatan konsentrasi kortisol plasma secara generalnya proporsional dengan mintensitas stimulasi: peningkatan level kortisol yang lebih besar, menandakan adanya respon terhadap kejadian cemas berat dibanding kejadian cemas yang sederhana (Sherwood, 2010).

Pada penelitian ini juga ditemukan bahwa mayoritas responden yang mengalami kecemasan juga mengalami Pre menstruasi syndrom. Uji statistik fisher's exact test (lampiran), diperoleh nilai signifikansi yang bermakna yakni $0.000<\alpha 0.005$ yang berarti ada hubungan yang bermakna antara Kecemasan dengan kejadian Pre Menstrual Syndrom pada mahasiwi DIV Kebidanan di STIKes Mega Resky Makassar. Hal ini sesuai dengan yang dikemukakan oleh Safaria \& Saputra (2009), yang menyatakan bahwa penderita sindrome pramenstruasi cenderung akan mengalami kecemasan berupa perasaan cemas yang berarti kecemasan erat hubungannya dengan kejadian Premestruasi Syndrome. Hal senada juga dengan temuan lestari (2015), yang juga menemukan Adanya hubungan sindrom pramenstruasi dengan tingkat kecemasan pada siswi kelas XI jurusan Akutansi SMKN 1 Bantul, dibuktikan dengan nilai signifikansi $\mathrm{P}<0,05$.

Kecemasan merupakan masalah emosional yang paling umum dialami wanita saat premenstrual syndrome dan hal ini sering menjadi sumber kecemasan bagi wanita. Yinghui (2011), dalam penelitiannya menenukan bahwa terdapat sekitar 20\% kecemasan yang diakibatkan oleh sindrom pramenstruasi dari populasi dunia dan sebanyak 48\% dialami oleh wanita usia subur.

Dalam teori yang dikemukan oleh Carpenito (2012), dijelaskan bahwa penyebab pasti munculnya kecemasan dalam menghadapi premenstrual syndrome diantaranya adalah faktor hormonal pada tubuh wanita, yaitu ketidak seimbangan antara hormon estrogen dan progesteron. Kecemasan yang tidak diatasi segera akan dapat menimbulkan berbagai respon 
kecemasan, antara lain gelisah, keringat dingin, takut, dan berbagai gangguan kesehatan yang dapat mengganggu aktivitas sehari-hari. Hal ini perlu mendapat perhatian guna mengurangi kecemasan, yaitu salah satunya dengan cara memberikan informasi yang benar sehubungan dengan kecemasannya. Gaya hidup sehari-hari perlu diatur untuk meminimalkan gejala yang timbul akibat perubahan hormonal. Salah satu hormon yang berhubungan dalam respon stress atau cemas yakni kortisol.

Kortisol merupakan respon fisiologis terhadap kondisi psikologis berupa cemas sebagai akibat dari sekresi beberapa hormon dan neurotransmitter didalam tubuh. Hormon-hormon ini mempersiapkan tubuh untuk menahan stressor dan penting untuk pertahanan mental dan fisik. Kelenjar Adrenal yang menyebabkan hipota-lamus menghasilkan dan melepaskan CRH kedalam sistem aliran darah portal hipotalamus-hipofisis, CRH menyebab-kan hipofisis anterior mengeluarkan ACTH. Hormon ini beredar kedalam korteks adrenal menyebabkan pelepasan hormon glukokortikoid yaitu kortisol. Sehingga terjadi sekresi kortisol yang berlebihan dari kelenjar adrenal yang akan mengakibatkan terjadinya syndroma premenstrual.

Hasil penelitian menunjukkan bahwa bahwa dari 27 responden yang mengalami PMS tedapat $26(92 . \%)$ responden yang memiliki kortisol tidak normal sedangkan yang normal hanya $1(8.3 \%)$ dan dari 13 responden yang Non PMS terdapat 2 (7.1\%) responden yang kadar kortisolnya tidak normal sedangkan yang kortisolnya normal sebanyak 11 (91.7\%) responden. Hasil uji statistik fisher's exact test (lampiran) menunjukkan bahwa nilai signifikansi atau $P$ Value $=0.000<\alpha 0.005$ yang dimana Ho ditolak dan Ha diterima yang berarti bahwa kadar kortisol mempunyai hubungan dengan kejadian Premenstrual Syndrome pada mahasiwi DIV Kebidanan di STIKes Mega Resky Makassar.

Hal ini sejalan dengan yang di kemukakan oleh Brunne \& Suddarth yang menyebutkan bahwa terdapat hubungan yang rumit antara ketidak seimbangan hormon yang dapat menyebabkan terjadinya sindroma premesntrual ini. Kortisol yang dilepaskan saat terjadinya stres dapat menghambat pelepasan dari GnRH, LH, dan estrogen. Kortisol juga dapat menurunkan sensitivitas target organ pada estrogen. Proses inilah yang dapat memicu dan memperberat gejala-gejala dari Premenstrual Syndrome. Kadar kortisol yang tinggi bisa menyebabkan stress. Pada stress terjadi penurunan serotonin yang mengakibatkan ketidakstabilan mood sehingga bisa memudahkan munculnya premenstrual syndrome (Kathleen et al., 2010). 


\section{KESIMPULAN DAN SARAN}

\section{A. KESIMPULAN}

Berdasarkan hasil penelitian tentang Hubungan antara Kecemasan dan kadar kortisol terhadap kejadian premenstrual syndrome maka dapat ditarik kesimpulan sebagai berikut:

1. Sebanyak $89 \%$ responden mengalami cemas pada saat PMS dengan kadar kortisol yang tidak normal.

2. Frekuensi tertinggi yang mengalami kecemasan yaitu wanita yang mengalami PMS, sementara frekuensi tertinggi yang tidak mengalami kecemasan adalah wanita yang tidak mengalami PMS.

3. Kecemasan dan kadar kortisol yang mempunyai hubungan secara langsung adalah Kortisol dan untuk variabel cemas pada tabel diatas ditemukan bahwa cemas tidak memiliki hubungan secara langsung terhadap premenstrual syndrome

4. Kecemasan dan kadar kortisol mempengaruhi terjadinya premenstrual syndrome, dari kedua variabel tersebut kortisol merupakan penyebab langsung terjadinya premenstrual syndrome dan faktor yang berperan dalam peningkatan kortisol adalah CRH-ACTH.

\section{B. SARAN}

Berdasarkan hasil penelitian yang dilakukan, adapun saran yang dapat diberikan yaitu sebagai berikut;

1. Bagi Institusi

Perlunya pendidikan kesehatan tentang premenstrual syndrome pada mahasiswi melalui pendekatan teori ataupun praktek yang lebih komprehensif.

2. Bagi Peneliti lain

Diharapkan agar peneliti selanjutnya meneliti hormone lainnya selain kortisol seperti hormone estrogen dan progesterone yang juga berperan pada kejadian premenstrual syndrome. 


\section{DAFTAR PUSTAKA}

Balaha M.H., Amr M. A. E. M., Moghannum M.S.A., \& Muhaidab N.S.A. 2010. The phenomenology of premenstrual syndrome in female medical students: a cross sectional study. PanAfrican Medical Journal. 5:4

Basir A. A., Bahrun U., \& Idris I. 2011. Peran High Sensitivity C-Reactive Protein (hs-CRP) Sebagai Penanda Inflamasi, Indeks Massa Tubuh, \&Lingkar Pinggang Terhadap Derajat Premenstrual Syndrome Pada Wanita Usia Subur. Retrieved from http://pasca.unhas.ac.id/jurnal/files/.pdf. Diakses 08 Januari 2017

Carpenito L.J. 2012. Buku Saku Diagnosa Keperawatan. Edisi 13 . Jakarta: EGC

Delara M., Ghofranipour F., Tavafian S.S., Kazemnejad A., \& Montazeri A. 2012. Health related quality of life among adolescents with premenstrual disorders: a cross sectional study. Health and Quality of Life Outcomes. Biomed Central. 10:1

Kathleen M., Lustyk B., \& Gerrish W.G. 2010. Premenstrual syndrome and premenstrual dysphoric disorder: issues of quality of life, stres and exercise. Springer Science+Bussiness Media LCC, USA.

Lestari C. P. 2015. Hubungan Sindrom Pramenstruasi Dengan Tingkat Kecemasan Pada Siswi Kelas Xi Jurusan Akutansi Smk Negeri 1 Bantul Yogyakarta. Retrieved from http://opac.unisayogya.ac.id/364/pdf. 08 Januari 2017

Mahajan A. S. 2010. Stres in medical education: a global issue or much a do about nothing specific?. South-East Asian Journal of Medical Education. 4(2): 9-13

Mohamadirizi S. \& Kordi M. 2013. Association between menstruation signs and anxiety, depression, and stress in school girls in Mashhad in 2011-2012. Iranian Journal of Nursing and Midwifery Research. Retrieved from http://www.ncbi.nlm.nih.gov/pmc/articles/PMC3877464/?report=reader. Diakses 08 Januari 2017

Pratita R. \& Margawati A. 2013. Hubungan Antara Derajat Sindrom Pramenstruasi Dan Aktivitas Fisik Dengan Perilaku Makan Pada Remaja Putri. Journal of Nutritin College. Retrieved from http://ejournal-s1.undip.ac.id/index.php/jnc/article/pdf. Diakses 08 Januari 2017

Sasaki K. J. 2014. Menstruation disorder in Adolescents. Retrieved from http://emedicine.medscape.com/article/953945-overview. Diakses 08 Januari 2017

Safaria T. \& Saputra N. E. 2009. Manajemen Emosi: sebuah Panduan Cerdas Bagaimana Mengelola Emosi Positif dalam Hidup Anda. Bumi Aksara. Jakarta.

Suparman \& Ivan. (2011). Premenstrual Syndrome. Jakarta : EGC

Sherwood L. 2010. Fisiologi Manusia : dari sel ke system. Edisi 6. Jakarta : EGC

Wahyuni. 2012. Hubungan Tingkat Kecemasan dengan Premenstrual Syndrome Pada Siswi Smp Negeri 4 Surakarta. Gaster, Vol. 7, No. 2. Retrieved from http://www.jurnal.stikes-aisyiyah.ac.id/index.php/gaster/article/viewFile/15/12. 08 Januari 2017

Yinghui X. et al. 2011. Are premenstrual symptoms associated with health anxiety in nursing 
graduates. Gynecology \& Obstetrics. Pp. 98-105. Retrieved from http://www.SciRP.org/journal/OJPsych/. Diakses 08 Januari 2017 